Adıyaman Üni. Sağlık Bilimleri Derg, 201.; 3(2):526-533

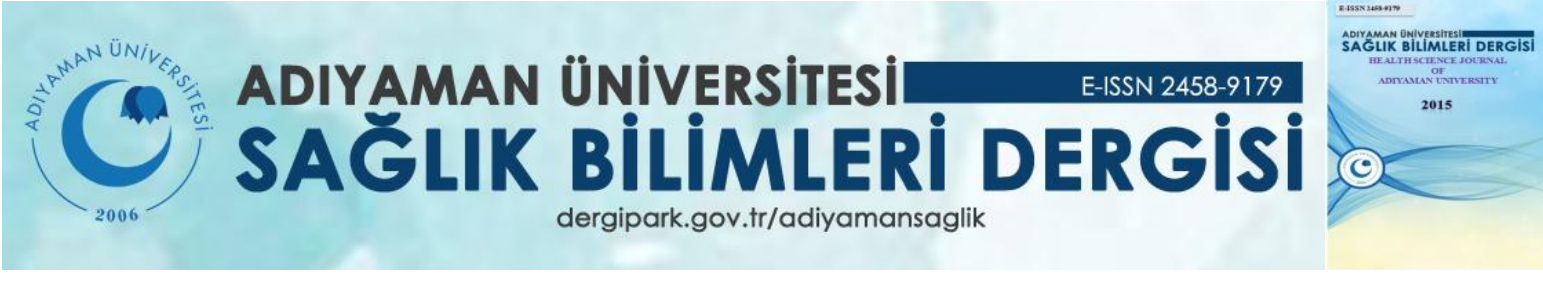

Olgu sunumu/ Case report

\title{
Süper Yapıştırıcı Kullanımı Sonucu Gelişen Korneal Abrazyon Olgusu
}

Mübeccel BAĞDAŞ ${ }^{1}$, Şemsettin BİLAK ${ }^{1}$, Ali ASGAR YETKİN ${ }^{1}$

${ }^{1}$ Adıyaman Üniversitesi, Eğitim ve Araştırma Hastanesi, Göz Hastalıkları Anabilim Dalı, Adıyaman,

\section{ÖZET}

65 yaşında kadın hasta kliniğimize sağ gözüne göz damlası olduğunu düşünerek süper yapıştırıcı (siyanoakrilat) damlatması sonucu oluşan yapışıklık nedeni ile başvurdu. Yapılan biyomikroskopik muayenesinde kapaklarında yapışıklık, kornea ve konjonktiva üzerinde kalınlaşmış yoğun bir yapıştırıcı tabakası izlendi. Hastanın görmesi el hareketleri düzeyinde idi. Diğer göz bulguları normal idi. Oküler yüzeydeki kesif yapıştırıcı tabaka penset yardımı ile kaldırıldığında, korneada totale yakın epitel defekti olduğu görüldü. Topikal prezervansız suni gözyaşı, antibiyotik tedavisi ve göz kapama ile iki hafta içinde korneanın sekelsiz epitelize olduğu görüldü.

Bu olgumuzda oküler ilaçlar ile karışabilecek süper yapıştırıcıların klinik bulgularını ve tedavisindeki yaklaşımımızı sunduk.

Anahtar Kelime; süper yapıştırıcı, kornea, korneal abrazyon,

\section{Yazışmadan Sorumlu Yazar}

Mübeccel BAĞDAŞ

Adıyaman Üniversi Tıp Fakültesi

Göz Hastalıkları Anabilim Dalı .

Tel : +900506 6589974

Email: mubeccelbagdas@gmail.com
DOI: 10.30569/adiyamansaglik.376330

\begin{tabular}{ll}
\hline Geliş Tarihi: & 09.01 .2018 \\
\hline Kabul Tarihi: & 19.02 .2018
\end{tabular}




\section{Corneal Abrasion Due To Super Glue Use}

\section{Summary}

A sixty-five years old female patient applied to our clinic with adhesion her right eyelash due to inadvertently used super glue instead of eye drop. Ophthalmologic examination showed;adhesion of right eyelash,a thick,opac layer on conjonktiva and cornea.Visual acuity was hand motion. Her left eye was normal. When we removed;thick,opac layer on ocular surface there was an epitelial defect near total. Corneal abrasion get better with topical antibiotic drop and artificial tears preservan-free for two weeks.

This case presents that; especially older patients may use super glues instead of ocular medications by mistake,consequently they have ocular tissue damage.

Key Words; Super Glue, Cornea, Corneal Abrasion, 


\section{GİRIŞ}

Süper yapıştırıcılar; siyanoakrilat türevleri kimyasal madde içeren ve metal, cam, kağıt, plastik yapıştırmaya yarayan kuvvetli yapıştırıcılardır (1). Siyanoakrilat formaldehit ve siyanoasetat'ın yoğunlaşması ile oluşan adhezif özelliğe sahip kimyasal bir monomerdir (2). Siyanoakrilat yapıştırıcılar ilk olarak 1950'li yılların sonunda kullanılmaya başlanmıştır (3). Günümüzde kolay ulaşılabilirliği, ucuz olması, güçlü yapıştırıcı özelliği sayesinde evde, endüstride, sanatta ve kozmetik alanda oldukça yaygın olarak kullanılır hale gelmiştir $(4,5)$. Süper yapıştırıcı kutularının göz damla ve merhemlerinin kutularına benzediği nedeniyle özellikle çocuklarda ve ileri yaş grubundayanlışlıkla kullanma sonucu oküler yaralanmalara neden olabilmektedir $(6,7)$.

$\mathrm{Bu}$ çalışmada topikal oftalmik ilaç sanılarak yanlışlıkla siyanoakrilat yapıştırıcı kullanımına bağlı meydana gelen oküler yaralanma olgusunu, klinik ve tedavi yaklaşımları ile birlikte sunmayı planladık. Çalışmanın literatürekatkı sunacağı kanaatindeyiz.

\section{OLGU SUNUMU}

Olgumuz 65 yaşında kadın hasta olup, ağrı ve görme kaybı şikâyeti ile polikliniğimize başvurdu. Hastanın öyküsünde; yaklaşık iki saat kadar önce sağ gözünde batma nedeni ile ilaç (damla) damlattığı ve sonrasında görme kaybının geliştiğini ifade etti. Damla sonrası gözünde ağrı, görme kaybı ve kapaklarında yapışıklık şikâyeti artması sonucunda kullanılan maddenin (damla) süper yapıştırıcı olduğu fark edilerek hastaneye başvurduğu öğrenildi.

Topikal anestezik (proparakain) damla ile yapılan klinik muayenesinde; görme seviyesi sağda el hareketleri düzeyinde, solda tashihsiz tam olarak değerlendirildi. Yapılan biyomikroskopik muayenesinde ise; sağ göz kirpiklerinde yapışıklık, alt ve üst konjonktival forniks dâhil tüm kornea ve konjonktiva yüzeyini kaplayan yoğun ve kalın bir yapıştırıcı 
tabakası tespit edildi (Resim 1, 2). Sol gözün biyomikroskobik muayene bulguları normal olarak değerlendirildi.

Okuler yüzeydeki tabaka topikal anestezi altında penset yardımı ile kaldırıldı. Kapak altlarına bakıldı ve oradaki parçalarda alındı. Bol serum fizyolojik ile yıkandı. Bir damla Fluorecein damlatılarak kobalt mavisi ile kornea incelendiğinde totale yakın kornea abrazyonu görüldü (Resim 3). Prezervansız suni gözyaşı, topikal netilmisin damla ve fusidik asit, siklopentolat \%1 ve oral NSAİ tedavisi başlandı. Hasta iki hafta boyunca takip edildi. İki hafta sonraki kontrolde epitel dokunun kornea yüzeyinde kapmasını tamamladığı tespit edildi (Resim 4). Sağ göz görmesi 0,7 hafif bir nükleer katarakt ve fundus doğal, sol göz muayenesi normal olarak değerlendirildi.
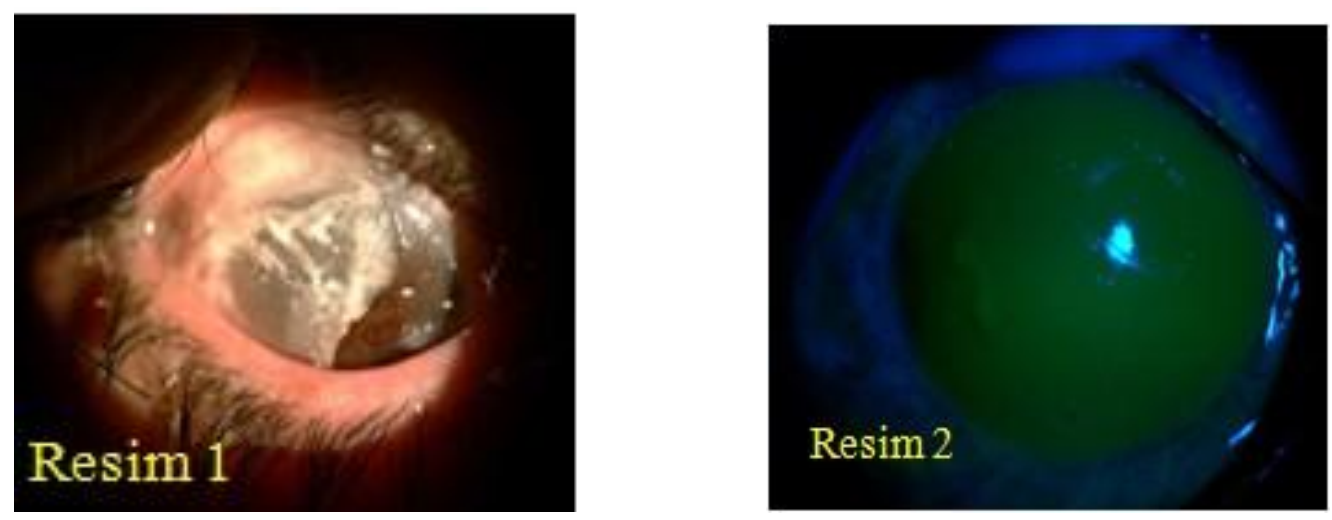

Şekil 1 ve 2. Konjonktiva yüzeyini kaplayan yoğun ve kalın bir yapıştırıcı tabakası

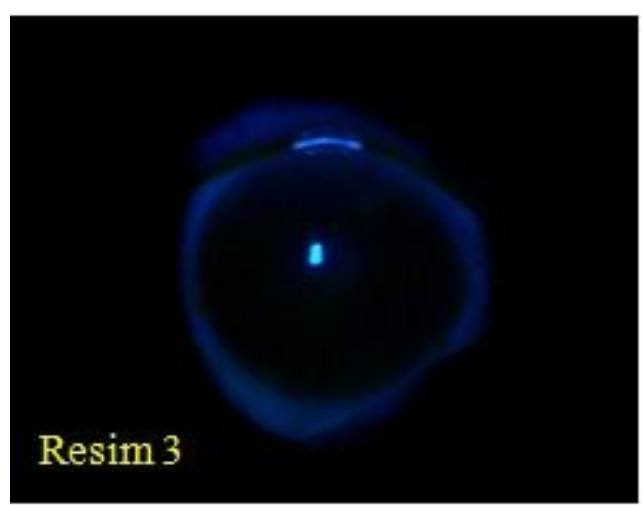

Şekil 2. Kornea abrazyon

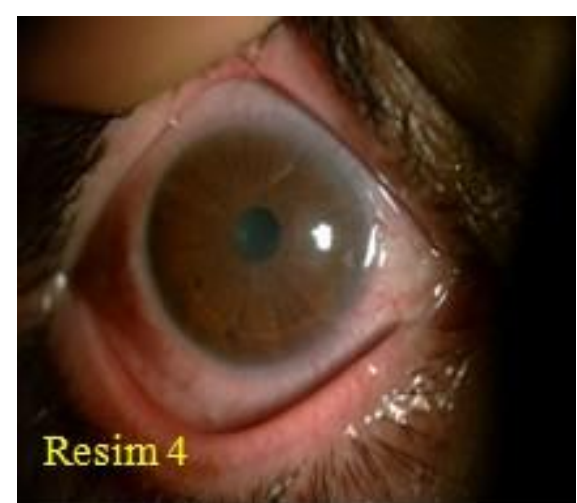

4. Epitel dokunda remisyon 


\section{TARTIŞMA}

Litaratürde çoğu çocuk olmak üzere acil servislere süper yapıştırıcı yanlışlıkla kullanımı nedeni ile başvuran birçok hasta vardır $(6,8,9)$. Genellikle iyi göremeyen yaşlı hastalarda; kutularının benzerliği sebebi ile göz damlası sanılıp kullanılması, çocuklarda;yapıştırıcılar ile oynarken ve bazen de bebeklerde ailelerin dikkatsizliği sonucu oluşur (9). Hastamız okuma yazma bilmeyen sosyokültürel düzeyi düşük bir hastaydı. Buna bağlı olarak gözünde oluşan hafif bir batma nedeni ile göz damlasına benzettiği yapıştırıcıyı gözüne damlatt1.

Süper yapıştırıcı kullanımı sonucu oluşan okuler yaralanmalarda genelde dermatit, kirpik kaybı, ankleblefaron, şiddeti göz ağrısı, konjonktival veya korneal abrazyon, punktat keratopati şeklinde bulgular olmaktadır. Yapıştırıcının kornea ve konjonktiva ile teması kimyasal keratite, oluşturduğu tabakanın mekanik etkisi ile travmatik kerotopatiye neden olur (4). Literatürdeki süper yapıştırıcı acillerinin çoğu kirpik ve göz kapağı yapışıklığı şeklindedir (9). Bunun sebebi göze damla geleceği zaman refleks olarak gözün kapatılıp göz kapağı ve kirpiklerin hasar görmesidir (ankleblefaron) (10). Olgumuzda kirpiklerde ve göz kapaklarında yapışıklık, konjonktival hiperemi ve korneal abrazyon oluşmuştu.

Bildirilen tedavi yaklaşımları ise kirpiklerdeki yapıştırıcıları keserek uzaklaştırmak, irrigasyon, konjonktival ve korneal yapıştırıcı varsa forceps yardımı ile temizlemek, korneal abrazyon varlığında topikal antibiyotik, siklopentolat tedavisi ve göz kapamadır.

Literatürdeki bir çalışmada süper yapıştırıcı yaralanması ile acile başvuran üç pediatrik vakanın ikisinde göz kapaklarında ve kirpiklerde yapışıklık diğerinde de bunlara ilaveten korneal abrazyon bildirilmiştir. Göz kapakları asetonla temizlenmeye çalışılsa da sonuç alınamamış kirpikleri kesilerek yapıştırıcı temizlenmeye çalışılmıştır. Bu vakalar gentamisin damla ile,korneal abrazyon olanda sedasyon altında forceps yardımı ile yapıştırıcı 
temizlendikten sonra topikal gentamisin ve siklopentolat tedavisi ile takip edilip sekelsiz iyileşmiştir (9).

Siyanoakrilatlar doku yapıştırıcısı olarak oftalmoloji cerrahisinde de kullanılmaktadır. Korneal perforasyon,ülserasyon,blefaroplasti, punktal tıkaç uygulanması ve tarsorafi gibi cerrahilerde kullanılmaktadır $(2,11)$. Medikal kullanımda ise doku toksisitesi daha azla olduğu belirtilmiştir $(10,12)$.

Korneal abrazyon; travma, yabancı cisim, kontakt lens kullanımı sonrası gelişen korneal epitel defektidir. Tırnaklar, kâğıt kenarı, makyaj malzemesi ucu, ağaç dalı/yaprağı gibi yabancı cisimler sorumludur. Göz acilleri içinde yaklaşık \%10-15 yer tutar. Olgular ağrı, yanma-batma, fotofobi ve sulanma şikayeti ile başvururlar. Biyomikroskopik muayenede kornea fluorecein ile boyanma gösterir. Tedavide topikal antibiyotikler, sikloplejikler ve bandaj kontakt lens tercih edilir.

Olgumuzda önce acil servisde irrigasyon uygulanmıştı. Biz de topikal anestezik damlatarak yapıştırıcı tabakasını kaldırdık, kapak altlarına da bakıp fornixleri temizledik.İrrigasyon yaparak kalan küçük partikülleri uzaklaştırdık.Korneayı fluorecein damla ile boyayıp tekrar baktımızda totale yakın abrazyon gördük. Topikal antibiyotik ve siklopentolat tedavisi ile iki hafta sonunda epitelin kapandığını tespit ettik.

Yusuf ve arkadaşlarının yapmış olduğu siyanoakrilat ile oküler yaralanmalarının tarandığı bir literatür çalışmasında bizim kullandığımız tedavi protokolüne benzer bir tedavi uygulandığı görülmektedir (1).

Çocuklarda, görmesi düşük olgularda ve dikkatsizlik sonucu siyanoakrilat yapıştırıcılarla çeşitli oküler yaralanmalar olabildiği gibi sosyokültürel düzeyi düşük olgularda 
da okuma bilmediği için göz damlalarına benzerliği nedeni ile oküler yaralanmalar meydana gelebilmektedir.

$\mathrm{Bu}$ olgularda primer tedavi siyanoakrilatın hızla uzaklaştırılması şeklinde olmalıdır. Daha sonra ise oküler yüzeydeki hasara göre tedavi planın yapılması akılcı yaklaşım alacaktır. 


\section{KAYNAKLAR}

1. Yusuf IH, Patel CK. A Sticky Sight: Cyanoacrylate 'Superglue' Injuries Of The Eye. BMJ Case Rep. 2010;11:2009-2435.

2. Vote BJ, Elder MJ. Cyanoacrylate Glue for Corneal Perforations: A Description of A Surgical Technique and A Review of The Literature. Clin Experiment Ophthalmol .2000; 28(6): 437-42

3. How Everyday Products Make People Sick : Toxins at Home and in the Workplace ,Paul D. Blanc, CA: University of California Press; 2007

4. .McLean CJ. Ocular Super Glue Injury. AccidEmergMed. 1997;14(1):40-1.

5. Reddy SC. Superglueinjuries of the eye. Int J Ophthalomol. 2012;5(5):634- -

6. Mandal A, Imran D, Erdmann MW. Inadvertent application of Super Glue As Eye Ointment. IrMed J. 2003;96(10):310-311.

7. Cao H, Li L, Zhang M, Li H. Epidemiology of pediatricoculartrauma in the Chaoshan Region, China, 20012010. PLoSOne. 2013;8(4):e60844.

8. Margo CE, Trobe JD. Tarsorrhaphy From Accident Alinstillation of Cyanoacrylat Adhesive in The Eye. JAMA .1982; 247(5): 660-1

9. Sagili Chandrasekhara Reddy. Superglue injuries of the eye.Int J Ophthalmol.2012;5(5):634-7

10. Ankur Yadav,Vishal Katiyar, Komal D. Singh, Pawan Kumar Yadav, Vinita Singh. Self-Inflicted accidental chemical injury to eye. International Journal of Ocular Oncology and Oculoplasty. 2017;3(1):437

11. Golubovic S, Parunovic A. Cyanoacrylate Glue in The Treatment of Corneal Ulcerations. For tschr Ophthalmol. 1990; 87(4): 378-81

12. Spencer TJ, Clark B. Self-inflicted Superglue Injuries. Med J Aust 2004; 181(6): 341. 